\title{
ASSAY OF XYLANOLYTIC ACTIVITY OF MUTANTS OF NEUROSPORA CRASSA (EMA 5297) INDUCED WITH ULTRA-VIOLET RADIATION
}

\author{
Nelofar Yesmin", Tahsina Haque, Mozmader Tima and Suman Mohajan ${ }^{1}$ \\ Department of Botany, University of Dhaka, Dhaka-1000, Bangladesh
}

Key words: Mutation, Mutants, Xylanase enzyme, Enzymatic activity

\begin{abstract}
Mutation was induced in Neurospora crassa (Ema 5297) with UV (having the wave length of $254 \mathrm{~nm}$ ) irradiation. Three groups of biochemical mutants (leucine, tryptophan and arginine) were obtained. Ema and 7 leucine mutants were used to evaluate whether mutation has any considerable effect for the production of such enzyme. Enzymatic activity was expressed as International Unit (IU). It was found that $N$. crassa mycelia secrete xylanases to the culture supernatant. Mutant Y10 showed highest xylanase activity (1.663 IU) and wild $N$. crassa (Ema) showed lowest (0.416 IU) activity.
\end{abstract}

For commercial production of enzymes filamentous fungi are mostly preferred because the enzymes produced by these fungi are more efficient as compared to those obtained from yeast and bacteria (Bakri and Thonert 2003). Neurospora crassa (Ascomycetes), a non-pathogenic filamentous fungus, is of particular interest to biologists due to their ability to produce hydrolytic enzymes, such as cellulases, amylases and chitinases, which are of special interest due to their importance in biotechnological processes (Benoliel et al. 2005) and its use in the study of genetic and metabolic pathways. For efficient enzyme production strains can be improved by mutagenesis which is successful method. This process is mostly trial and error process involving laborious steps of procedures in performance (Baker 1991, Iftikhar et al 2010). Ultraviolet light has been widely used in inducing mutations in the field of microbial breeding (Gadgil et al. 1995, Adsul et al. 2007). Kuek and Kidby (1984) improved the glucoamylase production over $140 \%$ after UV mutagenesis in Aspergillus pheonesis. Similar improvement related to cellulolytic enzymes was achieved by Szczodrak (1989) after mutagenesis of Trichoderma reesii. In this study, an attempt was taken to produce mutants of $N$. crassa for evaluation of xylonite activities compared to the wild type and also to evaluate whether mutation has any considerable effect for the production of such enzymes.

Wild type strains of Neurospora crassa Emerson a (5297) was received from Fungal Genetics Stock Centre, Kansas, USA. Five days old conidia of Ema (5297) were irradiated with UV light having the wave length of $254 \mathrm{~nm}$ for 120 and 180 seconds. Radiation was given at a distance of $15 \mathrm{~cm}$. Vogel's minimal medium (Vogel 1956) supplemented with arginine, leucine, tryptophan and lysine were used for plating the irradiated conidia and isolating conidial cultures, respectively. The isolates were incubated at $25^{\circ} \mathrm{C}$. After 5 days, the isolates were classified according to their nutritional requirements. For induction of mutation procedures of Catcheside (Catcheside 1954) were followed.

For the study of enzyme activities, wild and mutants of $N$. crassa were grown on VM liquid medium (supplemented for biochemical mutants) separately in which the glucose was replaced by xylan at $0.5 \%(\mathrm{w} / \mathrm{v})$ concentration. The fungi were incubated at $30^{\circ} \mathrm{C}$ for 3 days in shake culture.

*Author for correspondence: <nyasmin2012@gmail.com>. ${ }^{1}$ Department of Microbiology, Bangladesh Jute Research Institute, Manik Mia Avenue,Dhaka-1207, Bangladesh. 
The mycelia and other non-soluble material in the culture filtrates were separated by centrifugation at $15,000 \mathrm{rpm}$ for $5 \mathrm{~min}$. Then the culture supernatant was diluted three times before use. The clear supernatants were used for enzyme assays $(0.2 \mathrm{ml}$ supernatant with $1.8 \mathrm{ml}$ substrate (1\% xylan in citrate buffer, $\mathrm{pH}$ 6.5) in each case). For this purpose, standard curves of reducing sugar for xylanase assay were prepared. Reducing sugars were determined by measuring the absorbance at $540 \mathrm{~nm}$. Hydrolytic activity was calculated by measuring the amount of reducing sugars released from xylan. The amount of reducing sugar produced was measured by the DNS method (Miller 1959) using xylose as standards for xylanase activities.

Mutation was induced with UV having the wave length of $254 \mathrm{~nm}$. The treatment period of Ema conidia were 120 and 180 seconds. Three groups of biochemical mutants were obtained (Table 1). The highest frequency of the mutant was leucine (64.85\%).The best treatment period was 120 seconds. Seven leucine bio-chemical mutants were selected for enzymatic studies. UV irradiated 120 seconds mutans were Y1, Y4, Y5, Y7, Y10 and 180 seconds were Y32 and Y41. These were used for extracellular xylanase production in submerged cultures. Enzyme activities were calculated by the amount of reducing sugar (Table 2) obtained from standard curve prepared for xylanase (Fig. 1).

Table 1. Classification of biochemical mutants on the basis of their nutritional requirement

\begin{tabular}{|c|c|c|c|c|c|}
\hline Group & $\begin{array}{l}\text { Name of the } \\
\text { mutants }\end{array}$ & $\begin{array}{r}\begin{array}{r}\text { Time of } \\
\text { treatment }\end{array} \\
120^{\prime \prime}\end{array}$ & $\begin{array}{r}\begin{array}{r}\text { No. of } \\
\text { mutants }\end{array} \\
180^{\prime \prime}\end{array}$ & $\begin{array}{c}\text { Total } \\
\text { number }\end{array}$ & $\begin{array}{c}\text { Frequency } \\
(\%)\end{array}$ \\
\hline $\mathrm{A}$ & Leucine & 12 & 10 & 22 & 62.86 \\
\hline B & Tryptophan & 09 & 03 & 12 & 34.29 \\
\hline $\mathrm{C}$ & Arginine & - & 01 & 01 & 2.85 \\
\hline
\end{tabular}

Table 2. Reducing sugar of xylanase obtained from standard curve.

\begin{tabular}{ccccc}
\hline $\begin{array}{c}\text { Name and no. } \\
\text { of mutants }\end{array}$ & $\begin{array}{c}\text { Assay sample } \\
\text { (OD) }\end{array}$ & $\begin{array}{c}\text { Assay control } \\
\text { (OD) }\end{array}$ & $\begin{array}{c}\text { OD of } \\
\text { xylanase }\end{array}$ & $\begin{array}{c}\text { Reducing sugar of } \\
\text { xylanase }(\mathrm{mg} / \mathrm{ml})\end{array}$ \\
\hline Ema & 0.101 & 0.053 & 0.048 & 0.104 \\
Y1 & 0.118 & 0.060 & 0.058 & 0.126 \\
Y4 & 0.151 & 0.058 & 0.093 & 0.202 \\
Y5 & 0.162 & 0.072 & 0.090 & 0.196 \\
Y7 & 0.204 & 0.068 & 0.136 & 0.296 \\
Y10 & 0.241 & 0.050 & 0.191 & 0.416 \\
Y32 & 0.194 & 0.065 & 0.129 & 0.281 \\
Y41 & 0.174 & 0.062 & 0.112 & 0.244 \\
\hline
\end{tabular}

During the experiments it was found that $N$. crassa secretes xylanase to the culture supernatant, since activity was detected in mycelium cultures of the fungus. The cultures grown on xylan yielded detectable activities. But this xylanase activity of wild type was found to be lower than the UV ray induced mutated $N$. crassa. Wild (Ema 5297) showed lowest xylanase activity (0.416 IU), mutant-Y10 showed highest (1.663 IU) and mutant-Y7 showed second highest (1.184 IU) activity (Fig. 2). Although xylanase activity of wild type N. crassa (Ema 5297) found to be similar as reported earlier by Rahim (2001), Ray and Rahim (2012), the activity of xylanase enzyme of the UV ray induced morphological and biochemical mutants of N. crassa was found to be higher than the activity of wild type, is supported by some UV mutant studies (Sadana et al. 1980, Mohamed et al. 2011). 




Fig 1. Standard curve of xylose.

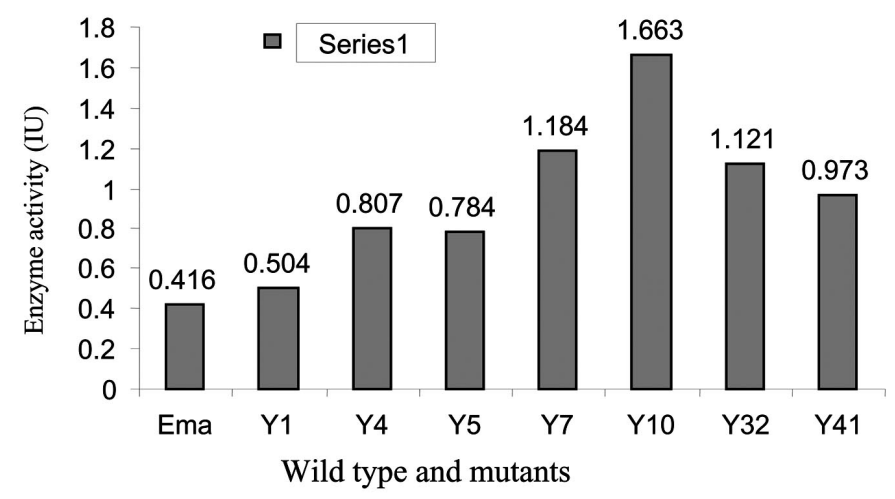

Fig 2. Xylanase activity of wild type and leucine mutants of N.crassa.

The xylanase activity was found to be the most important hydrolytic activity, being related to the hydrolysis of hemicellulose. Xylan is the main component of hemicellulose (Thomson 1993). The enzymatic assays of this study indicate the presence of a hydrolytic system in N. crassa, which was able to grow in media containing xylan as the sole carbon source. Besides, these findings revealed that mutation is not deleterious in all cases but advantageous for pure research and applied field. UV mutation is a random mutation. So it may cause some unknown genetic change in the gene that is responsible for xylanase production. This change might be beneficial for xylanolytic activity of mutants of $N$. crassa.

\section{Acknowledgements}

The authors are grateful to Dr Ishidore Gomes (CSO) and Dr Aleya Nasreen (PSO), Bangladesh Jute Research Institute (BJRI), Dhaka for providing laboratory and experimental supports. 


\section{References}

Adsul MG, Bastawde KB, Varma AJ and Gokhale DV 2007. Strain improvement of Penicillium janthinellum NCIM 1171for increased cellulase production. Biores. Technol. 98: 1467-1473.

Baker HV 1991. GCR-1 of Saccharomyces cerevisiae encodes a DNA binding protein whose binding is abolished by mutations in the CTTCC sequence motif. Process Nat. Acad. Sci. 88: 944.

Bakri YP and Thonart JP 2003. Xylanase production by Penicillium canescens 10-10c in solid-state fermentation. Appl. Biochem. Biotechnol. 108: 737-748.

Benoliel B, Arraes FBM, Reis VC, Siqueira SJL, Parachin NS and Torres FAG 2005. Hydrolytic enzymes in paracoccidioides brasiliensis - Ecological aspects. Genet. Mol. Res. 4(2): 450-461

Catcheside DG 1954 Isolation of Nutritional mutants of . crassa by filtration enrichment. Gen. Microbiol. 11:34.

Gadgil NJ, Daginawala HF, Chakrabarti T and Khanna P 1995. Enhanced cellulase production by a mutant of Trichoderma reesei. Enzyme Microbial Technol. 17: 942-946.

Girio FM, Fonseca C, Carvalheiro F, Duarte LC, Marques S and Bogel-£ukasik R 2010. Hemicelluloses for fuel ethanol: A review. Biores. Technol. 101: 4775-4800

Iftikhar T, Niaz M, Abbas SQ, Zia MA, Ashraf I, Lee KJ and Haq I 2010. Mutation induced enhanced biosynthesis of lipases by Rhizopus oligosporus var. microspores. Pak. J. Bot. 42: 1235-1249.

Kuek C and Kidby DK 1984. Screening fungi for improved glucoamylase productivity using buffered dextran broth culture. Biotechnol. lett. 6: 561-566.

Kumar R, S Singh and Singh OMV 2008. Bioconversion of lignocellulosic biomass: biochemical and molecular perspectives. J. Ind. Microbiol. Biotechnol. 35: 377-391.

Li X, She Y, Sun B, Song H, Zhu Y, Lv Y and Song H 2010. Purification and characterization of a cellulasefree, thermostable xylanase from Streptomyces rameus L2001 and its biobleaching effect on wheat straw pulp. Bioch. Engin. J. 52: 71-78.

Miller GL 1959. Use of dinitrosalicylic acid reagent for determination of reducing sugars. Anal. Chem. 31: 426-428.

Mohamed SAA, Fatma NT, Mohamed F, Azza AA, Ahmed SAR 2011. Improvement of xylanase production from Streptomyces pseudogriseolus via UV mutagenesis. Aust. J. Basic \& Appl. Sci. 5(5): 1045

Rahim T 2001. Genetical and biochemical investigations and protoplast fusion of anthranilic acid mutants of Neurospora crassa. Ph.D. thesis. Department of Botany, University of Dhaka.

Ray AL and Rahim T 2010. Cellulase and Xylanase Activities of Mutants of Neurospora crassa Induced with Leaf Extract of Abroma augusta L. Bangladesh J. Sci. Ind. Res. 45(2): 151-154.

Sadana JC, Shewale JG, and Deshpande MV 1980. High Cellobiase and Xylanase Production by Sclerotium rolfsii UV-8 Mutant in Submerged Culture. Appl. Environ. Microbiol. 39(4): 935-936.

Sharma P and Bajai BK 2005. Production and partial characterization of alkalitolerant xylanase froman alkali-tolerant xylanase from an alkalophilic Streptomyces sp. CD3. J. Sci. Indust. Res. 64: 688-697.

Szczodrak J 1989. The use of cellulases from a ó-glucosidase-hyperproducing mutant of Trichoderma reesei in simultaneous saccharification and fermentation of wheat straw. Biotechnol. Bioeng. 33: 1112-1116.

Thomson JA 1993. Molecular biology of xylan degradation, FEMS Microbiol. Lett. 104: 65-82.Viikari L, Kantelinen A, Sundguist J and Linko M 1994. Xylanases in bleaching, from an idea to the industry. FEMS Microbiol. Rev. 13: 335-350.

Vogel HJ 1956. A convenient growth medium for Neurospora crassa. Microbial Genetics Bull. 13: $42-43$. 